Prevalence of Human Herpes Viruses in Bronchoalveolar Lavage of Critically Ill Children Undergoing Mechanical Ventilation at a

\title{
Pediatric Intensive Care Unit
}

\author{
Ali Amanati, ${ }^{1}$ Abdollah Karimi, ${ }^{2,}$ Alireza Fahimzad, ${ }^{2}$ Ahmad Reza Shamshiri, ${ }^{3}$ Fatemeh Fallah, ${ }^{2}$ Alireza \\ Mahdavi, ${ }^{4}$ and Mahshid Talebian ${ }^{5}$ \\ ${ }^{1}$ Alborzi Clinical Microbiology Research Center, Shiraz University of Medical Sciences, Shiraz, Iran \\ ${ }^{2}$ Pediatric Infections Research Center, Research Institute for Children Health, Shahid Beheshti University of Medical Sciences, Tehran, Iran \\ ${ }^{3}$ Department of Epidemiology and Biostatistics, School of Public Health, Tehran University of Medical Sciences, Tehran, IR Iran \\ ${ }^{4}$ Pediatric Anesthesiologists and Intensivist, Mofid Children's Hospital, Shahid Beheshti University of Medical Sciences, Tehran, IR Iran \\ ${ }^{5}$ BS of Nursery, Head Nurse of PICU, Mofid Children's Hospital, Shahid Beheshti University of Medical Sciences, Tehran, IR Iran \\ "Corresponding author: Abdollah Karimi, Pediatric Infections Research Center, Department of Pediatric Infectious Diseases, Mofid Children's Hospital, Shahid Beheshti \\ University of Medical Sciences, Tehran, IR Iran. Dr. Shariati Ave., P.O.BOX: 1546815514, Tehran, IR Iran. Tel/Fax: +98-2122226941, E-mail: dr_akarimi@yahoo.com
}

Received 2017 March 06; Revised 2017 November 24; Accepted 2018 February 21.

\begin{abstract}
Background: Critically ill children at the intensive care unit frequently develop hospital-acquired pneumonia (HAP). Human herpes viruses (HHVs), primarily or by reactivation may cause bronchopneumonitis in mechanically ventilated patients. The exact prevalence and role of HHVs in morbidity and mortality of pediatric patients undergoing mechanical ventilation is unclear. The current study was conducted to evaluate the prevalence of 5 Herpes viruses by polymerase chain reaction (PCR) method in bronchoalveolar lavage (BAL) samples in critically ill children at a pediatric intensive care unit (PICU).

Methods: Overall, 140 bronchoalveolar lavage samples from 83 mechanically ventilated cases were studied. Samples were taken via the mini-BAL technique. Samples were analyzed by qualitative PCR for detection of herpes simplex virus type 1 and 2 (HSV1/HSV2), human herpes virus type 6 and 7 (HHV6/HHV7), Ebstein-Barr virus (EBV), and cytomegalovirus (CMV).

Results: Out of 83 cases, 53\% (44) were male and 47\% (39) were female. The mean age was $29.12 \pm 33.67$ months (32.53 months in males and 25.29 months in females). The estimated prevalence of HSV1, HHV6, HHV7, EBV, and CMV were 2.4\%, 13.2\%, 2.4\%, 7.2\%, and $2.4 \%$, respectively.

Conclusions: Molecular study of BAL specimens and investigation of HHVs may be the first step in the evaluation of the possible role of these viruses in the development of viral pneumonia during VAP. The current results are useful for guiding other well-designed studies for correlation of viral load and clinical outcome in ill ventilated children. The Modified protected BAL may be of use as a safe modality in critically ill ventilated pediatric patients for investigation of possible viral (and also bacterial and fungal) infections. Local study of high-risk patients at the PICU and estimation of the true prevalence of HHVs infection may assist in finding the exact role of HHVs in mortality and morbidity of critically ill patients.
\end{abstract}

Keywords: Human Herpes Viruses, Protected Bronchoalveolar Lavage, Pneumonia, Ventilator-Associated, Polymerase Chain Reaction

\section{Background}

Diagnostic virology has become one of the integral parts of managing patients with respiratory infection (1-5). Along with recent advantages in diagnosis (6), new challenges have occurred in the management of viral infections (true disease versus colonization), especially among high risk patients (such as immunocompromised hosts). Also, there are limited data regarding the clinical importance of isolated virus (such as HHVs) in lower respiratory tract of critically ill individuals. Pulmonary viral infections have been reported in both immunocompromised (7) and healthy individuals (8). Currently, there is a lack of acceptable evidence-based approach for the management of patients, who are infected with latent viruses, especially Herpes viruses. These viruses can reactivate any time throughout life $(9,10)$ after primary infection.

Pulmonary viral infections (primary or reactivation) $(6,11,12)$ may be accompanied by susceptibility to certain bacterial or fungal infections $(4,13,14)$ and further complications (15-17).

Differentiation of true infection from asymptomatic colonization may not be feasible in all situations. At the 
time of reactivation, the virus may be excreted through the respiratory and digestive tract (17). On the other hand, viruses could excreted in colonization, persistent or chronic infections (18).

Incidence of pulmonary Herpes virus infections in high risk healthy individuals is not yet fully determined.

Detection of the virus from the tissue, CSF, skin lesions, eye, and blood is more likely to be associated with clinical disease but positive tests of bronchoalveolar lavage sampling may be due to active disease or asymptomatic infection (colonization) (19).

Human herpes viruses (HHVs) are one of the most common causes of respiratory viral infections in immunocompromised patients $(1,20)$. Although cytomegalovirus (CMV) is a known cause $(21,22)$, other members of this family may cause pneumonia in both healthy and immunocompromised individuals $(3,23,24)$. Patients with acute respiratory distress syndrome (ARDS) and acute lung injury (ALI) or viral pneumonia of unknown etiology should be examined for HHVs $(1,24)$.

CMV pneumonia could occur in the absence of antigenemia or detectable pp65 (25) and this fact necessitates the use of other available diagnostic methods, such as molecular tests in bronchoalveolar lavage samples, for better detection of causative viral infections.

Published reports have shown that patients with ventilator associated pneumonia (VAP), who are infected with certain HHVs have poorer prognosis than non-infected individuals (26-29). However, other researchers have failed to find any differences $(3,12,30)$. Thus, the clinical importance of HHVs infection in critically ill patients, is a subject of discussion and needs further well-designed observational studies (27, 30-32).

The majority of previous reports have investigated these viruses in high risk populations, such as in lung transplant patients (33). There are limited studies that have evaluated HHVs in critically ill pediatric patients (1).

This study was conducted to estimate prevalence of HHVs in bronchoalveolar lavage samples of children requiring mechanical ventilation.

\section{Methods}

In this cross-sectional study, 83 patients were included and 140 BAL samples were obtained from critically ill ventilated patients at the PICU by protected mini BAL (without bronchoscopy). Samples were taken by covered catheter to minimize the risk of contamination. During the study period, all critically ill ventilated patients younger than 18 years of age, who were admitted to the PICU, were enrolled and investigated. Any intubated child with pulmonary hemorrhage (or bleeding tendency) and unstable respiratory condition were excluded. Three samples were taken from each patient. The first sample was taken within 24 hours after intubation, the second sample was taken 48 hours after the first sample, and finally, the third sample was taken 1 week after the intubation time.

Sampling was continued as long as the patient was under mechanical ventilation, thus a lesser count of samples was obtained in total (compared to the maximum number of samples that could be obtained from all patients). It should be noted that repeated sampling was primarily achieved as part of VAP assessment (bacterial and viral detection), however, there was a chance to increase the likelihood of HHVs detection. These results have been published separately (34).

A protected double catheter was advanced in the airway, where the inner catheter is then released to perform a small lavage and collect the specimen. During sampling, 5 to $10 \mathrm{~mL}$ of sterile normal saline was slowly injected and immediately suctioned. During sampling, sterile gloves and standard precautions were applied. The patient was observed closely by an assistant physician for any change in vital signs and also any possible clinical deterioration. $\mathrm{FiO}_{2}$ was increased temporarily and close heart and respiratory monitoring was done during each sampling. Each specimen was transferred to the Pediatric Infections Research Center, Shahid Beheshti University of Medical Sciences, Tehran, to freeze at $-70^{\circ} \mathrm{C}$. At the end of the specimen collection period, specimens were obtained from the freezer and prepared to processing. The HHVs DNA were determined by the commercially available qualitative conventional PCR method. Primers were provided by the Takapozist company from Bioneer (South Korea). A master mix kit, manufactured by Intron (South Korea; Accu Power PCR Premix cat No K-2016), was used for DNA extraction. Taq polymerase, buffers, dNTPs, and MgCI2 were used according to the company recommendations. The used primers are presented in Table 1.

\subsection{Informed Consent}

Informed parental consent was obtained from all participants included in the study.

\subsection{Ethical Approval}

All procedures were in accordance with ethical standards of the institutional and/or national research committee and with the 1964 Helsinki declaration and its later amendments or comparable ethical standards. This study was approved by pediatric infections research center review board of Shahid Beheshti University of Medical Sciences. 
Table 1. Primers Used for Detection of Different HHVs PCR

\begin{tabular}{lll}
\hline Primers & & \\
\hline HSV1 R & TTTTCTGCTCCAGGCGGACT & Tm 58.4 \\
\hline HSV1 F & AGCGTCTTGTCATTGGCGAA & Tm 57.8 \\
\hline HHV6 R & GGTGCTGAGTGATCAGTTTC & Tm 48.9 \\
\hline HHV6 F & TTCTCCAGATGTGCCAGGGA & Tm 57.5 \\
\hline HHV7 R & CACAAAAGCGTCGCTATCAA & Tm 53.8 \\
\hline HHV7 F & CGCATACACCAACCCTACTG & Tm 52.7 \\
\hline EBV R & AGTCTGGGAAGACAACCACA & Tm 51.4 \\
\hline EBV F & CCCGCCTACACACCAACTAT & Tm 53.7 \\
\hline CMV R & ATAGGAGGCGCCACGTATTC & Tm 55.4 \\
\hline CMV F & TACCCCCTATCGCGTGTGTTC & $\operatorname{Tm} 54.6$ \\
\hline
\end{tabular}

In this study, known risk factors for development of bacterial VAP was investigated in patients with HHVs (35). To address this correlation, 6 parameters were investigated in all ventilated patients, including the use of PH modifying agents, corticosteroid therapy, total or partial parenteral nutrition, concurrent antibiotic therapy, presence of nasogastric tube, and immune status.

Pneumonia was categorized to "bacterial, viral, and aspiration" by clinical history, imaging findings, laboratory criteria, and microbiology confirmation, if available.

Qualitative data were reported as frequencies and percentages. Quantitative data were reported as mean and standard deviation. Statistical significance was considered at $\mathrm{P}$ values of $\leq 0.05$. Each patient provided routine care and proper antimicrobial treatment based on clinical judgment of the responsible physician.

\section{Results}

Out of 83 patients, 44 cases were male (53\%) and 39 patients (47\%) were female. The average age of patients was 29 months (the youngest was 1 month and the oldest was 12 years old). Overall, 19 patients were positive for HHVs. Among them, HSV1-PCR was found in 2 patients (2.4\%), HHV6-PCR in 11 patients (13.2\%), HHV7-PCR in 2 patients (2.4\%), EBV-PCR in 6 patients (7.2\%), and CMV-PCR in 2 patients (2.4\%). Of the 140 samples, 26 specimens (22.9\%) had positive test results. In the patients with positive results, 3 cases had 2 positive HHV-6 tests in repeated sampling and in 1 case all 3 samples were positive for CMV.

The HHV-6 and EBV virus was detected in 2 samples (codetection). Also, EBV/HSV-1 and HHV6/HSV1 were detected in 2 different samples.
Characteristics of positive samples, according to specific virus based on clinical course and outcome are summarized in Table 2.

Among patients infected with HHVs, 52.63\% cases were less than 12 months of age, $26.32 \%$ were older than 5 years old and the rest (21\%) were between 1 and 5 years of old. The most common diagnosis at the time of sampling included aspiration pneumonia in 19 cases (22.9\%), bacterial pneumonia in 13 cases (15.7\%), seizure in 11 (13/3\%), viral pneumonia (by PCR confirmation) in 3 cases (3.6\%), heart failure in 3 cases (3.6\%), metabolic disorder in 2 cases (2.4\%), leukemia or lymphoma in 2 cases $(2.4 \%)$, and prolonged intubation after surgery (with no medical problems) in 5 cases (6\%).

The researchers attempted to investigate the possible effect of different risk factors for HHVs infection in critically ill patients at the PICU. The rate of HHVs infection was not different between immunocompromised and immunocompetent cases (P value $=0.393$ ). Among other possible predisposing risk factors for acquisition of HHVs infection, history of corticosteroid therapy and concurrent use of total or partial parenteral nutrition were investigated, however, no significant differences were found between those with and without HHVs infection ( $\mathrm{P}$ value $=$ 0.527 and Pvalue $=0.264$, respectively). Demographic characteristics and investigated risk factors are summarized in Table 3.

Prevalence of risk factors according to presence of HHVs infection are shown in Figure 1.

Critically ill patients with acute respiratory disorders are more commonly infected with HHVs compared to those admitted with other diagnoses ( $P$ value $<0.002$ ). Data are shown in Table 4.

The mortality rate (all-cause mortality) was not statistically different between HHVs infected and non-infected patients $(P$ value $=0.597)$.

The incidence of HHV infection was not significantly greater in those, who developed early ( $\mathrm{P}$ value $=0.698$ ) or late VAP $(P$ value $=0.778)$. Detail information about the incidence of VAP in our cases also is reported by authors (34).

\section{Discussion}

The current study was conducted on a pediatric population and not limited to a high risk population (for example septic or immunocompromised patients). The study included all ventilated patients regardless of primary diagnosis.

Prevalence of HHVs in critically ill ventilated patients was investigated in different population. Prevalence, outcome, and findings of some reports in pediatric and adult patients are shown in Table 5 and compared with the present study. 
Table 2. Characteristics of Isolated Virus by Clinical Course and Risk Factors

\begin{tabular}{|c|c|c|c|c|c|c|}
\hline & HSV-1 & HSV-2 & HHV-6 & HHV-7 & CMV & EBV \\
\hline Number of positive samples & 2 & 0 & 14 & 2 & 6 & 6 \\
\hline Number of repeated positive samples in one patients & - & - & $3^{\mathrm{a}}$ & - & $1^{\mathrm{b}}$ & - \\
\hline Co-detection ${ }^{c}$ & Yes & - & Yes & No & No & Yes \\
\hline Prolonged PICU stay before intubation (number of patients) & No & - & Yes $(1)$ & Yes (1) & No & Yes $(2)$ \\
\hline Number of positive samples in patients with more than 4 risk factors & 1 & - & 5 & 1 & 2 & 2 \\
\hline $\begin{array}{l}\text { Abbreviation: PICU, pediatric intensive care unit. } \\
\text { a Three patients had two repeated positive tests. } \\
\text { b One patient had three repeated positive tests. } \\
\text { c At least two HHVs in one patient. }\end{array}$ & & & & & & \\
\hline
\end{tabular}

\section{Prevalence of Different Risk Factors in HHVs Positive and HHVs Negative Patients}

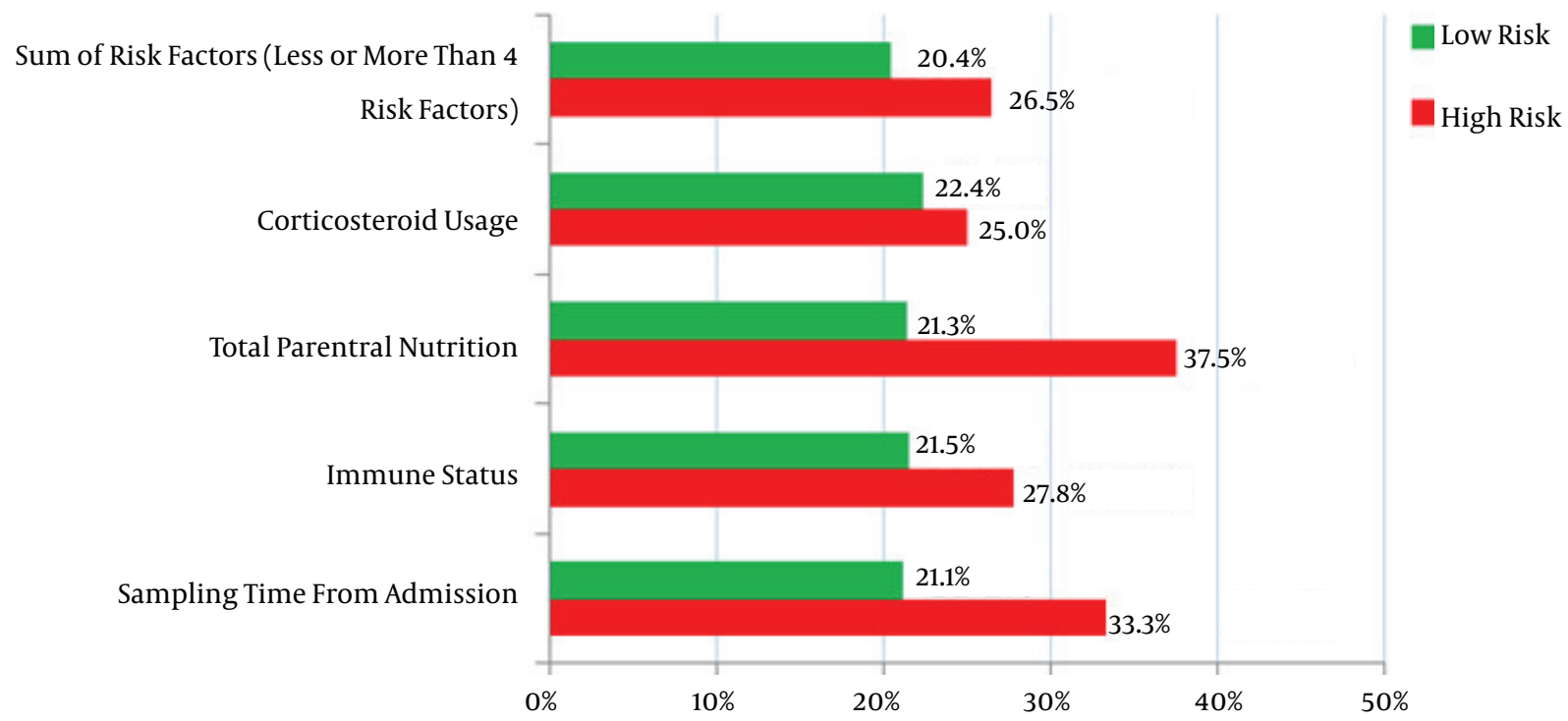

None of investigated risk factors had a significant role in HHVs acquisition in critically ill children. (Green column represents absence of previous history of corticosteroid therapy, concurrent TPN administration during repeated sampling, immunocompetent individuals, first sample obtained in less than one week after admission and less than 4 risk factors). [Calculated $P$ value in descending order: 0.349, 0.527, 0.264, 0.393 and 0.277].

Out of 83 patients, 19 cases (22.89\%) had at least one HHV in their BAL samples. Prevalence of different HHVs in the ventilated patients at the PICU was 13.2\% for HHV6, 7.2\% for EBV, and 2.4\% for HHV7, CMV, and HSV1. Furthermore, HSV-2 was not detected in any of the patients. In comparison to previous reports that estimated lower prevalence of HHVs at the intensive care unit (ICU) (less than 5\%) (37-39), there was a notably greater prevalence of HHVs at the PICU in our study.

In previous studies, CMV and EBV were of the most common herpes viruses detected in different settings in patients with VAP. The reported incidence of CMV among VAP events in ICU patients had a wide range between 0 to $36 \%$ (28). For example, in a study by Bewig et al. in an adult population, CMV was the most commonly detected HHVs (24\%) in new onset acute lung injury or ARDS patients. The other less common isolated viruses in this study were EBV: 18\%, HSV-1: 13\%, HHV-6: $2 \%$ and HHV-7: $1 \%$ (40). In another study by Germi et al. EBV was the most common isolated virus (28\%) followed by CMV/HHV-6 (18\%) and HSV-1 (12\%) 
Table 3. Prevalence of Isolated Virus in Patients with Acute Respiratory Disorders ${ }^{\mathrm{a}}$

\begin{tabular}{|c|c|c|c|}
\hline & \multicolumn{2}{|c|}{ Respiratory Disorder $^{\text {b }}$} & \multirow[t]{2}{*}{ P Value } \\
\hline & No & Yes & \\
\hline Patients HHV status & & & 0.002 \\
\hline Negative & $49(87.5)$ & $15(55.6)$ & \\
\hline Positive & $7(12.5)$ & $12(44.4)$ & \\
\hline
\end{tabular}

Table 4. General Description and Distribution of Isolated Virus Among Samples Collected by BAL ${ }^{\mathrm{a}}$

\begin{tabular}{|c|c|c|}
\hline Variables (Total Number) & HHVs Positive & P Value \\
\hline Male $(n=44)$ & $11(57.9)$ & \multirow{2}{*}{0.794} \\
\hline Female $(n=39)$ & $8(42.1)$ & \\
\hline \multicolumn{2}{|l|}{ Age } & 0.15 \\
\hline$<12 \mathrm{mo}(\mathrm{n}=35)$ & $10(52.63)$ & \\
\hline $1-5 y(n=33)$ & $4(21)$ & \\
\hline$>5 y(n=15)$ & $5(26.32)$ & \\
\hline Bacterial pneumonia $(n=13)$ & $3(15.8)$ & 0.67 \\
\hline \multicolumn{2}{|l|}{ Immune status } & 0.54 \\
\hline Immunocompetent $(n=65)$ & $14(73.7)$ & \\
\hline Immunocompromised $(\mathrm{n}=18)$ & $5(26.3)$ & \\
\hline \multicolumn{2}{|l|}{ Corticosteroid usage } & \multirow{3}{*}{$\begin{array}{c}0.52 \\
>0.999\end{array}$} \\
\hline Yes $(n=16)$ & $4(21.1)$ & \\
\hline No $(n=67)$ & $15(78.9)$ & \\
\hline \multicolumn{2}{|l|}{ Partial Parenteral Nutrition } & 0.52 \\
\hline Yes $(n=8)$ & $3(15.8)$ & \multirow{2}{*}{0.376} \\
\hline No $(n=75)$ & $16(84.2)$ & \\
\hline \multicolumn{2}{|l|}{ Number of risk factors } & \multirow[t]{2}{*}{0.599} \\
\hline Less than $4(n=49)$ & $10(52.6)$ & \\
\hline More than $4(n=34)$ & $9(47.4)$ & \\
\hline \multicolumn{2}{|l|}{ Sampling time from admission } & 0.609 \\
\hline Less than 1 week $(\mathrm{n}=71)$ & $15(78.9)$ & \\
\hline After 1 week $(n=12)$ & $4(21.1)$ & \\
\hline \multicolumn{2}{|l|}{ Survival } & $>0.999$ \\
\hline Survive $(\mathrm{n}=21)$ & $6(42.9)$ & \\
\hline Death $(n=25)$ & $8(57.1)$ & \\
\hline
\end{tabular}

${ }^{\mathrm{a}}$ Values are expressed as No. (\%).

(27). In a study by Linssen on adults, HSV-1 occurred more commonly in critically ill patients. Linssen showed that viral load was directly correlated with outcome (26). Based on the author's knowledge, this high prevalence of HHV6 among HHVs is not reported by other prospective studies on ventilated pediatric patients at the PICU.

Although there was no significant differences between clinical outcome (mortality) in $\mathrm{VAP}+/ \mathrm{HHV}+$ and $\mathrm{VAP}+/ \mathrm{HHV}-$ groups (Pvalue: 0.326), yet patients with positive HHVs had greater mortality (24.7\%), which is in agreement with previous reports $(13,21,41-45)$. On the other hand, patients with $\operatorname{VAP}(+)$ had a greater chance of HHVs positivity (36.8\%) than VAP $(-)$ patients $(18.7 \%)($ P value $=0.124)(34)$. These findings were also in agreement with previous reports, indicating the possible role of HHVs for participation in development of VAP, and its consequences, such as prolonged ICU or hospital stay $(29,46)$. The characteristics of VAP in our critically ill children undergoing mechanical has been published in other report (34).

This study failed to find any considerable risk factor in patients, who had HHVs in their BAL samples. Thus, known risk factors for the development of bacterial VAP should not be considered as a significant risk factor for acquisition of HHVs infection.

\subsection{Conclusions}

According to the author's experience, modified protected BAL sampling (as described in detail in the methodology section) could be used successfully in suspected or proven VAP patients. The researchers did not encounter any adverse events or any complications (whether early or late) after performing this method in critically ill children at the PICU. Because of feasibility of sampling by this technique compared to bronchoscopy, clinicians may have a greater chance to obtain suitable specimens for timely diagnosis of the suspected organism in critically ill children at the PICU. This technique has been compared with BAL via flexible bronchoscopy in children, indicating acceptable results $(47,48)$.

This study was conducted during more than 12 months (including 4 seasons) and also included a wide range of primary diagnoses (usual admission cause in PICU).

Given the very low prevalence of treatable HHVs (HSV1 and CMV) and lack of any strong effects on the outcomes, it could be concluded that HHVs has a small role in acute respiratory disorder of critically ill children at the PICU.

Further research should be conducted to determine the exact role of these viruses in the clinical course of acute respiratory disorders in critically ill pediatric patients at the PICU. Finally, HHVs are known viruses that have a "latency phase", and time of detection is not helpful to differentiate colonization (infection) and reactivation. This differentiation needs viral loading and well-designed studies to find the exact viral cutoff in virus reactivation. 
Table 5. Characteristics of the PRESENT Study in Comparison with Some Other Studies Assessing the Rate and Outcome of HHVs Isolation in Critically Ill Patients

\begin{tabular}{|c|c|c|c|c|c|c|c|c|c|c|c|}
\hline \multirow[b]{2}{*}{$\begin{array}{l}\text { Study [Reference } \\
\text { number] }\end{array}$} & \multicolumn{11}{|c|}{ HHVs Rate (Percent) } \\
\hline & $\begin{array}{l}\text { Inclusion Crite- } \\
\text { ria/(Population) }\end{array}$ & MV & $\begin{array}{c}\text { Number of Patients } \\
\text { (Samples) }\end{array}$ & $\begin{array}{c}\text { Frequency of } \\
\text { Monitoring }\end{array}$ & Assay (Specimen) & HSV-1/2 & HHV-6 & HHV-7 & CMV & EBV & $\begin{array}{l}\text { Outcome and } \\
\text { Findings }\end{array}$ \\
\hline $\begin{array}{l}\text { Present study } \\
\text { (Prospective) }\end{array}$ & $\begin{array}{l}\text { Any MV patient in } \\
\text { PICU (pediatric) }\end{array}$ & Yes & $83(140)$ & $\begin{array}{l}\text { Three times (within } \\
\text { first } 24 \mathrm{hr} \text {, after } 48 \mathrm{hr} \\
\quad \text { and on day } 7 \text { ) }\end{array}$ & $\begin{array}{c}\text { Conventional PCR } \\
\text { (Protected mini BAL) }\end{array}$ & $2.4 / 0$ & 13.2 & 2.4 & 2.4 & 7.2 & $\begin{array}{l}\text { HHVs do not affect } \\
\text { mortality }\end{array}$ \\
\hline $\begin{array}{l}\text { Tachikawa, 2014 } \\
\text { (Retrospective)(1) }\end{array}$ & $\begin{array}{l}\text { New onset ALI/ARDS } \\
\text { (Adult) }\end{array}$ & Yes & $87(87)$ & Once & $\begin{array}{l}\text { Multiplex PCR, } \\
\text { culture (BAL) }\end{array}$ & $13 / 0$ & 2 & 1 & 24 & 18 & $\begin{array}{l}\text { Detecting HHVs in } \\
\text { AL/ARDS patients }\end{array}$ \\
\hline $\begin{array}{l}\text { Germi, 2011 } \\
\text { (Retrospective) (27) }\end{array}$ & $\begin{array}{l}\text { Lung transplant } \\
\text { recipients (Adult) }\end{array}$ & No & $83(25)$ & . & PCR (BAL) & $12 / \mathrm{ND}$ & 18 & ND & 18 & 28 & $\begin{array}{l}\text { HHVs are more } \\
\text { frequently detected in } \\
\text { suspected LRI }\end{array}$ \\
\hline $\begin{array}{l}\text { Emilio Bouza, 2011 } \\
\text { (Retrospective) (4) }\end{array}$ & ICUs patients (Adults) & Yes & $177(177)$ & Once & $\begin{array}{l}\text { Viral culture } \\
\text { (Endotracheal } \\
\text { aspiration) }\end{array}$ & 19 & ND & ND & ND & ND & $\begin{array}{l}\text { HSV infection } \\
\text { associated with } \\
\text { greater severity and } \\
\text { worse prognosis }\end{array}$ \\
\hline $\begin{array}{l}\text { Astegiano, 2010 } \\
\text { (Prospective) (32) }\end{array}$ & $\begin{array}{l}\text { Transplant recipients } \\
\text { (Adult) }\end{array}$ & No & $153(212)$ & $\begin{array}{l}\text { At month } 1 \text { post Tx and } \\
\text { by 3-month intervals }\end{array}$ & Real-time PCR & $\mathrm{ND}$ & ND & 32.3 & $\mathrm{ND}$ & ND & $\begin{array}{l}\text { Quantification of } \\
\text { HHV-7 DNA in BAL } \\
\text { may be useful post TX }\end{array}$ \\
\hline $\begin{array}{l}\text { Van den Brink, 2004 } \\
\text { (Retrospective) (36) }\end{array}$ & $\begin{array}{l}\text { Critically ill patient in } \\
\text { ICU (Adult) }\end{array}$ & Yes & $22(22)$ & Once & Viral culture (BAL) & $25 / \mathrm{ND}$ & ND & ND & ND & ND & $\begin{array}{l}\text { HSV-1 may be a marker } \\
\text { rather than a } \\
\text { mediator of severe } \\
\text { illness }\end{array}$ \\
\hline $\begin{array}{l}\text { Tarp, 2001 } \\
\text { (Retrospective) (30) }\end{array}$ & HIV patients & No & $72(91)$ & Not defined & $\operatorname{PCR}(\mathrm{BAL})$ & $\mathrm{ND}$ & ND & ND & 36 & 5.5 & $\begin{array}{l}\text { HHVs do not play a } \\
\text { serious role in the } \\
\text { development of } \\
\text { pulmonary symptoms } \\
\text { in HIV patients }\end{array}$ \\
\hline
\end{tabular}

lung injury; ARDS, acute respiratory distress syndrome; BAL, bronchoalveolar lavage; HHVs, human herpes viruses; HIV, human immunodeficiency virus; ICU, intensive care unit; LRI, lower respiratory infection; MV, mechanical ventilation; $\mathrm{ND}$, not detected; $\mathrm{PCR}$ : polymerase chain reaction; PICU, pediatric intensive care unit: TX, transplatation; VAP, ventilator associated pneumonia.

\section{Acknowledgments}

The authors appreciate R. Farmani for English editing of the manuscript.

\section{Footnotes}

Funding/Support: There was no funding/support. Conflict of Interest: The authors had no potential conflicts of interest to disclose.

\section{References}

1. Tachikawa R, Tomii K, Seo R, Nagata K, Otsuka K, Nakagawa A, et al. Detection of herpes viruses by multiplex and real-time polymerase chain reaction in bronchoalveolar lavage fluid of patients with acute lung injury or acute respiratory distress syndrome. Respiration. 2014;87(4):279-86. doi:10.1159/000355200. [PubMed: 24334877].

2. Mahony JB. Nucleic acid amplification-based diagnosis of respiratory virus infections. Expert Rev Anti-Infect Ther. 2010;8(11):1273-92.

3. Scheithauer S, Manemann AK, Kruger S, Hausler M, Kruttgen A, Lemmen SW, et al. Impact of herpes simplex virus detection in respiratory specimens of patients with suspected viral pneumonia. Infection. 2010;38(5):401-5. doi: 10.1007/s15010-010-0036-x. [PubMed: 20589523].

4. Pillay D, Emery VC, Mutimer D, Ogilvie MM, Carman W, Mutton K, et al. Guidelines for laboratory monitoring of treatment of persistent virus infections. J Clin Virol. 2002;25(1):73-92. [PubMed: 12126724].

5. Bouza E, Giannella M, Torres MV, Catalan P, Sanchez-Carrillo C, Hernandez RI, et al. Herpes simplex virus: a marker of severity in bacterial ventilator-associated pneumonia. J Crit Care. 2011;26(4):432 e1-6. doi: 10.1016/j.jcrc.2010.10.008. [PubMed: 21129912].
6. Luyt CE, Brechot N, Chastre J. What role do viruses play in nosocomial pneumonia?. Curr Opin Infect Dis. 2014;27(2):194-9. doi: 10.1097/QCO.0000000000000049. [PubMed: 24492750].

7. Singh N. Interactions between viruses in transplant recipients. Clin Infect Dis. 2005;40(3):430-6. doi: 10.1086/427214. [PubMed: 15668868].

8. Ahmed A. Immunopathology of CMV Co-Infection: Review. MOJ Immunol. 2014;1(3). doi: 10.15406/moji.2014.01.00017.

9. Sinclair J, Sissons P. Latency and reactivation of human cytomegalovirus. J Gen Virol. 2006;87(Pt 7):1763-79. doi: 10.1099/vir.0.81891-0. [PubMed:16760381].

10. Stevens JG. Human herpesviruses: a consideration of the latent state. Microbiol Rev. 1989;53(3):318-32. [PubMed: 2552271].

11. Docke WD, Prosch S, Fietze E, Kimel V, Zuckermann H, Klug C, et al. Cytomegalovirus reactivation and tumour necrosis factor. Lancet. 1994;343(8892):268-9. [PubMed: 7905100].

12. Cook CH, Martin LC, Yenchar JK, Lahm MC, McGuinness B, Davies EA, et al. Occult herpes family viral infections are endemic in critically ill surgical patients. Crit Care Med. 2003;31(7):1923-9. doi: 10.1097/01.CCM.0000070222.11325.C4. [PubMed: 12847384].

13. Jaber S, Chanques G, Borry J, Souche B, Verdier R, Perrigault PF, et al. Cytomegalovirus infection in critically ill patients: associated factors and consequences. Chest. 2005;127(1):233-41. doi: 10.1378/chest.127.1.233. [PubMed: 15653989].

14. Chiche L, Forel JM, Roch A, Guervilly C, Pauly V, Allardet-Servent $\mathrm{J}$, et al. Active cytomegalovirus infection is common in mechanically ventilated medical intensive care unit patients. Crit Care Med. 2009;37(6):1850-7. doi: 10.1097/CCM.ob013e31819ffea6. [PubMed: 19384219].

15. Ghazal P, Garcia-Ramirez J, Gonzalez-Armas JC, Kurz S, Angulo A. Principles of homeostasis in governing virus activation and latency. Immunol Res. 2000;21(2-3):219-23. doi: 10.1385/IR:21:2-3:219. [PubMed: 10852120].

16. White DW, Suzanne Beard R, Barton ES. Immune modulation during latent herpesvirus infection. Immunol Rev. 2012;245(1):189-208. doi: 10.1111/j.1600-065X.2011.01074.x. [PubMed: 22168421]. 
17. Ling PD, Lednicky JA, Keitel WA, Poston DG, White ZS, Peng R, et al. The dynamics of herpesvirus and polyomavirus reactivation and shedding in healthy adults: a 14-month longitudinal study. J Infect Dis. 2003;187(10):1571-80. doi: 10.1086/374739. [PubMed: 12721937].

18. Schleiss MR. Persistent and recurring viral infections: the human herpesviruses. Curr Probl Pediatr Adolesc Health Care. 2009;39(1):7-23. doi: 10.1016/j.cppeds.2008.10.003. [PubMed: 19038775].

19. Linssen CFM. Diagnostic value of brochoalveolar lavage in infectious disorders. Maastricht university; 2007.

20. Chakraborty N, Bhattacharyya S, De C, Mukherjee A, Bhattacharya D, Santra S, et al. Incidence of multiple Herpesvirus infection in HIV seropositive patients, a big concern for Eastern Indian scenario. Virol J. 2010;7:147. doi: 10.1186/1743-422X-7-147. [PubMed: 20604948].

21. Heininger A, Jahn G, Engel C, Notheisen T, Unertl K, Hamprecht K. Human cytomegalovirus infections in nonimmunosuppressed critically ill patients. Crit Care Med. 2001;29(3):541-7. [PubMed: 11373417].

22. Schlischewsky E, Fuehner T, Warnecke G, Welte T, Haverich A, Ganzenmueller T, et al. Clinical significance of quantitative cytomegalovirus detection in bronchoalveolar lavage fluid in lung transplant recipients. Transpl Infect Dis. 2013;15(1):60-9. doi: 10.1111/tid.12015. [PubMed: 23025532].

23. Costa C, Elia M, Astegiano S, Sidoti F, Terlizzi ME, Solidoro P, et al. Quantitative detection of Epstein-Barr virus in bronchoalveolar lavage from transplant and nontransplant patients. Transplantation. 2008;86(10):1389-94. doi:10.1097/TP.0b013e3181890415. [PubMed: 19034008].

24. Versluys AB, Rossen JW, van Ewijk B, Schuurman R, Bierings MB, Boelens JJ. Strong association between respiratory viral infection early after hematopoietic stem cell transplantation and the development of life-threatening acute and chronic alloimmune lung syndromes. Biol Blood Marrow Transplant. 2010;16(6):782-91. doi: 10.1016/j.bbmt.2009.12.534. [PubMed: 20060053].

25. Landry ML. Multiple viral infections in the immunocompromised host: recognition and interpretation. Clin Diagn Virol.1994;2(6):313-21. [PubMed: 15566777].

26. Linssen CFM, Jacobs JA, Stelma F, van Mook WNKA, Drent M, Vink C, et al. Herpes simplex (HSV) viral load in bronchoalveolar lavage: risk factors and clinical outcome. J Clin Virol. 2006;36. S9. doi: 10.1016/s13866532(06)80723-7.

27. Germi RBN, Quetant S, Lupo J P, Bourgeois JM, Morand P. Measurement of HSV1, CMV, HHV6 and EBV viral loads in 83 bronchoalveolar lavage from lung transplant recipients. 2011.

28. Osawa R, Singh N. Cytomegalovirus infection in critically ill patients: a systematic review. Crit Care. 2009;13(3):R68. doi: 10.1186/cc7875. [PubMed: 19442306].

29. F.M. Linssen C, C.J.J. Bergmans D, N.K.A. van Mook W. Impact of Latent Viral Infections in Mechanically Ventilated Patients. Curr Respirat Med Rev. 2012;8(3):200-7. doi: 10.2174/157339812800493287.

30. Tarp B, Jensen-Fangel S, Dahl R, Obel N. Herpesvirus type 1-8 in BAL fluid from HIV-1-infected patients with suspected pneumonia and from healthy individuals. Eur Respir J. 2001;18(1):146-50. [PubMed: 11510785].

31. Riise GC, Andersson R, Bergstrom T, Lundmark A, Nilsson FN, Olofsson S. Quantification of cytomegalovirus DNA in BAL fluid: a longitudinal study in lung transplant recipients. Chest. 2000;118(6):1653-60. [PubMed: 11115455].

32. Astegiano S, Costa C, Terlizzi ME, Sidoti F, Gambarino S, Mantovani S, et al. Detection of human herpesvirus-7 DNA in bronchoalveolar lavage. Intervirology. 2010;53(2):119-23. doi: 10.1159/000264202. [PubMed: 19955817].

33. Costa C, Delsedime L, Solidoro P, Curtoni A, Bergallo M, Libertucci D, et al. Herpesviruses detection by quantitative real-time polymerase chain reaction in bronchoalveolar lavage and transbronchial biopsy in lung transplant: viral infections and histopathological correla- tion. Transplantation proceedings. Elsevier; 2010. p. 1270-4.

34. Amanati A, Karimi A, Fahimzad A, Shamshiri AR, Fallah F, Mahdavi A, et al. Incidence of Ventilator-Associated Pneumonia in Critically Ill Children Undergoing Mechanical Ventilation in Pediatric Intensive Care Unit. Children (Basel). 2017;4(7). doi: 10.3390/children4070056. [PubMed: 28671616].

35. Koenig SM, Truwit JD. Ventilator-associated pneumonia: diagnosis, treatment, and prevention. Clin Microbiol Rev. 2006;19(4):637-57. doi: 10.1128/CMR.00051-05. [PubMed: 17041138].

36. van den Brink JW, Simoons-Smit AM, Beishuizen A, Girbes AR, Strack van Schijndel RJ, Groeneveld AB. Respiratory herpes simplex virus type 1 infection/colonisation in the critically ill: marker or mediator?. J Clin Virol. 2004;30(1):68-72. doi: 10.1016/j.jcv.2003.09.003. [PubMed: 15072757].

37. Luyt CE, Combes A, Deback C, Aubriot-Lorton MH, Nieszkowska A, Trouillet JL, et al. Herpes simplex virus lung infection in patients undergoing prolonged mechanical ventilation. Am J Respir Crit Care Med. 2007;175(9):935-42. doi: 10.1164/rccm.200609-1322OC. [PubMed: 17234903].

38. Luyt CE, Combes A, Nieszkowska A, Trouillet JL, Chastre J. Viral infections in the ICU. Curr Opin Crit Care. 2008;14(5):605-8. doi: 10.1097/MCC.ob013e32830fie12. [PubMed: 18787457].

39. Daubin C, Vincent S, Vabret A, du Cheyron D, Parienti JJ, Ramakers $\mathrm{M}$, et al. Nosocomial viral ventilator-associated pneumonia in the intensive care unit: a prospective cohort study. Intensive Care Med. 2005;31(8):1116-22. doi: 10.1007/s00134-005-2706-1. [PubMed: 15999253].

40. Bewig B, Haacke TC, Tiroke A, Bastian A, Böttcher H, Hirt SW, et al. Detection of CMV pneumonitis after lung transplantation using PCR of DNA from bronchoalveolar lavage cells. Respiration. 2000;67(2):16672.

41. Chilet M, Aguilar G, Benet I, Belda J, Tormo N, Carbonell JA, et al. Virological and immunological features of active cytomegalovirus infection in nonimmunosuppressed patients in a surgical and trauma intensive care unit. J Med Virol. 2010;82(8):1384-91. doi: 10.1002/jmv.21825. [PubMed: 20572085].

42. Cook CH, Yenchar JK, Kraner TO, Davies EA, Ferguson RM. Occult herpes family viruses may increase mortality in critically ill surgical patients. Am J Surg. 1998;176(4):357-60. [PubMed: 9817255].

43. Bruynseels P, Jorens PG, Demey HE, Goossens H, Pattyn SR, Elseviers $\mathrm{MM}$, et al. Herpes simplex virus in the respiratory tract of critical care patients: a prospective study. Lancet.2003;362(9395):1536-41. doi: 10.1016/S0140-6736(03)14740-X. [PubMed: 14615108].

44. Linssen CF, Jacobs JA, Stelma FF, van Mook WN, Terporten P, Vink $\mathrm{C}$, et al. Herpes simplex virus load in bronchoalveolar lavage fluid is related to poor outcome in critically ill patients. Intensive Care Med. 2008;34(12):2202-9. doi: 10.1007/s00134-008-1231-4. [PubMed: 18679655].

45. Ziemann M, Sedemund-Adib B, Reiland P, Schmucker P, Hennig H. Increased mortality in long-term intensive care patients with active cytomegalovirus infection. Crit Care Med. 2008;36(12):3145-50. doi: 10.1097/CCM.ob013e31818f3fc4. [PubMed: 18936696].

46. Costa C, Sidoti F, Saldan A, Sinesi F, Balloco C, Simeone S, et al. Clinical impact of HSV-1 detection in the lower respiratory tract from hospitalized adult patients. Clin Microbiol Infect. 2012;18(8):E305-7.

47. Rosas-Salazar C, Walczak SA, Winger DG, Kurland G, Spahr JE. Comparison of two aspiration techniques of bronchoalveolar lavage in children. Pediatr Pulmonol. 2014;49(10):978-84. doi: 10.1002/ppul.22916. [PubMed: 24155175].

48. Busley R, Dietrich W, Braun S, Weipert J, Richter JA. Ventilatorassociated pneumonia in intubated children: comparison of different diagnostic methods. Critical Care. 2003;7(Suppl 1):1. doi: $10.1186 /$ cc2147. 